\title{
Father Figures
}

\author{
... in Egypt* \\ By MiHAiLA YoRdANOva
}

On January 29, the Facebook group Șuwar Mașr Zamān ("Pictures from Egypt in the Old Days") posts a photo of Gamal Abdel Nasser (Gamāl 'Abd al-Nāșir), in the company of a young bride and a sheikh. The caption tells a moving story: The girl on the photo is an orphan. She was about to get married but did not have a father or an uncle to act as her guardian during the ceremony. Fearing the judgment of her future husband's family, the girl wrote to Nasser in desperation, explaining her situation. The president soon showed up at her doorstep, bringing along the sheikh of al-Azhar to tie the knot. As one commentator points out, the photo is actually depicting the daughter of sheikh 'Abd al-Raḥmān Tāg, on her wedding day. But that does not stop the Facebook crowd from engaging in one of their typical quarrels, which often occur when the name of Abdel Nasser is mentioned. For many, the fictional story captures the essence of the former president. It shows him as a guardian, "a father to all orphans, poor and deprived Egyptian people." Or maybe just a leader who has fulfilled his legal obligations, as one anonymous soul points out, quoting the Prophetic tradition (hadith): "The sultan serves as a guardian to all those who have no guardian" [ IIn Islam, ... ]. To the other half, however, Nasser is synonymous with "tyranny," "oppression," "torture," "defeat in the Six-Day War," "an atheist," "an apostate." In the absence of debate, after 246 comments no consensus is reached on the question of who Abdel Nasser really was. It is the complex relationship with the Father Figure, evident in both Egypt and Tunisia; the powerful image of the Patriarch, representing both benevolent guidance and strict authority, which evokes admiration as well as the desire to rebel.

Occasionally both, as 'Awāțif 'Abd al-Raḥmān knows very well. The first part of Jīhān al-Tāhirī's trilogy Egypt's Modern Pharaohs, screened by BBC Arabic on the anniversary of the 2011 Revolution [ $\nearrow$ Commemoration / Memorial Days], shows the scholar and journalist talking about Nasser's death:

I was chatting with my brother about Abdel Nasser and the repression. We were saying that he had no option but to be patient for at least twenty more years since Abdel Nasser was young. He was only 51. We were criticizing Abdel Nasser's regime, the Party and its corruption and the Security State. Then I went home. Later, my brother called and his voice was very strange. I said: "What's wrong, Mālik?" He answered: "The President is dead." ... I threw the receiver and lost it. It was horrible, horrible, horrible. Until today I don't think I have ever mourned anyone, including my

* $\quad$ Re-published (with minor modifications, mainly in the cross-references) from JAIS 17 (2017): 492-98.

Journal of Arabic and Islamic Studies • 21 (2021) - Themed Section In2016: *111-*123 (C) Mihaila Yordanova, Brussels (for EG) $\mid$ Joachim Ben Yacoub, University of Ghent (for TN) 
father and mother, as much as I mourned Abdel Nasser... No one has the right to orphan an entire nation.

Decades after his death, Nasser's legacy is still a hot topic, and there is still an apparent need to talk about the events. In Egypt, his figure, much like that of former president Habib Bourguiba in Tunisia, is still casting its long shadow over the country's affairs. 'Abd alRaḥmān's comments also touch on the love-hate relationship she has with the previous president and the battle between the conscious and the emotional. The Father here, with all his positives and negatives, is the one who gives direction. Without him, Egypt has no clear path forward, is left without guidance and care, orphaned.

Yet, some go out of their way to show that the direction was actually not lost after his death. On August 27, the Facebook page al-Ra's̄s 'Abd al-Fattāh al-Sìsī posts a link to an article entitled "El-Sisi and Abdel Nasser: Two leaders fighting conspiracy" [ $\nearrow$ Past vs. Present]. The Americans have a masterplan, aimed at destabilizing Egypt and depriving the country of its independence, the article argues [ $\nearrow$ The Suspect Foreigner, $\nearrow$ True $=$ False (Life in Limbo)]. Under Nasser, they have refused to finance the Aswan High Dam, and have then attacked Egypt after the nationalization of the Suez Canal. Now, Obama's new Middle East plan is again aimed at harming Egyptian sovereignty, making it dependent on aid. And this is just the first part. Once Egypt has fallen, the rest of the Middle East will follow. The only difference, the author concedes, is that in the 1960s, Nasser was only facing external conspiracies. Today, el-Sisi is battling enemies from outside and the Muslim Brotherhood and their supporters from inside the country. Much like Nasser, however, elSisi is going to protect the country, ensuring its stability, security and independence [ $\nearrow$ Security $v s$. Fear]. He is ready to step into his predecessor's shoes and safely steer the country as long as the people and the political forces are behind him.

But el-Sisi embodies not just a continuation of Nasser's legacy, he is an upgrade. In December 2016, the following anecdote is posted on Khayr ajnād al-ard ("The Best Soldiers on Earth"):

Gamal Abdel Nasser built the High Dam and so he is a leader. Every day, we hear about the projects el-Sisi has completed or is going to complete, but that is normal and no one says a word. These are the words of my mother who is satisfied with you, Mr. President.

The current president does not receive enough praise for his achievements, his accomplishments are merely reported, without elevating el-Sisi to the high status that the ordinary citizen thinks he deserves, as the story suggests, emphasizing on the president's popular appeal. However, it is not just Nasser's legacy that he surpasses. On March 9, the Facebook group Maṣr lil-gamī'wa-bil-gamī ("Egypt for and through Everybody”) changes its status:

We have a president whose greatness and glory are equal to that of Ahmed 'Urabi, whose courage equals that of Gamal Abdel Nasser, who is intelligent like Sadat and who has true Muslim morals. His name is Mr. Abdel Fattah el-Sisi. 
Next to the text is a photo of the president, looking shyly away from the camera. The post is pointing out the virtues of the leader, presenting him as an embodiment of the best qualities of many of the paternal figures from the recent past - the ultimate Father Figure.

Mere admiration is not enough, however. The Father also requires obedience and faith in Him. He promises stability and security —on the condition that His authority is respected [ $\lambda$ Security $v s$. Fear]. In April, the announcement that the two Read Sea islands of Tìrān and Șanāfïr will be transferred to Saudi Arabia immediately prompts a wave of protests [ $\nearrow \operatorname{Red}$ Sea Islands]. But some Facebook users react in a very different way (\#al-Sīsī-șāyin-arḍoh [\#el-Sisi_protects_his_land], \#ad'am-qarārāt-al-Sīsīi [\#I_support_el-Sisi's_decisions], \#athiq_fì_al-ra'ī̄ al-Sī̄ī [\#I_trust_in_President_el-Sisi]). And the proclamation of trust goes beyond the usage of the folk taxonomy mark-up. On May 4, 2016, an apparent hardcore fan of el-Sisi (his face is beaming from her cover photo), posts on Facebook in defence of the president, accompanying her display of affection with the hashtag \#athiq_fĩ_al-ra'īs_al-Sìsī [\#I_trust_in_President_el-Sisi]). The post is a collage of six images. The upper four show cities devastated by war. Four bright words are written in Arabic above each of them: Syria, Libya, Iraq, Yemen. The emblematic Tahyā Mașr (Long Live Egypt) divides those images from the lower two photos: a picturesque view over Cairo at night and the smiling face of elSisi adorned with the caption "We must keep on thanking this hero". The message is clear: Stick with the Father Figure, for he is the only thing standing between Egypt and the devastation and destruction plaguing the region.

Yet, the president is not just a guardian and a leader. He is also caring and compassionate. "How can anyone believe that these eyes can sell the land?" asks a Facebook post from April 2016 rhetorically, showing two mirroring images of el-Sisi in tears, separated by a large red heart. Trust el-Sisi by supporting the hashtag, in recognition of the fact that he has sacrificed his life and peace of mind to protect the country! In the comment section, emotions run high. "I love you, Mr. President. Your tears are precious to us," "We love you because you are an officer, we love you because you are a president, we love you because you are tough, we love you because you are merciful..."

An officer, a president, an army man - he could never betray his country. After all, the army is there to protect the land, not sell it. El-Sisi knows best, The Father has a plan for the future of Egypt, he just needs a bit of trust and support from the Egyptian people and everything will be good again. He is a man of the people, a man of the army, and he has never forgotten his duties to Egypt, suggests a post shared on the Facebook page Kulluna rijäl alshurța al-mișriyya and the comments below it. Proudly carrying the hashtag \#ad'am-qarāaräal-Sīsī ("\#I-support-el-Sisi's-decisions"), the post also features a remarkable display of affection. To the right there is a photo of el-Sisi in a full military uniform and sunglasses staring at the horizon, a faint smile on his lips. To the left: a heavily armed group of soldiers, posing in front of the Egyptian flag. The president, in civilian clothes, standing in the middle, embraces the soldier kneeling in from of him. One word, written in large Latin characters, floats over the two images: Boba (i.e., Arabic $b \bar{a} b \bar{a}$ ' dad'). A sign of respect and affection, the epithet hints at the president's fatherly appeal, but it also points to another function of his. $\mathrm{He}$ is to be obeyed and loved, his authority unquestioned, his fatherly advice always followed $[$ [ Security $=$ Fear (Police State) $]$.

As the paternal advice often comes in large quantities, that is not always an easy task.

jais • 21 (2021) - Themed Section In2016: *111-*123 
"What's this rubbish song you put on?," "Don't you have any other clothes?," "Sweat away now, as you did nothing at school," "You are praying five times a day and when I was your age, I was praying seven times a day," "You are now 20. When I was your age, I was more like 22," "Your mom back in the day. Oh, how she chased me" [ IInferiority $=$ Superiority (Satire) $]$.

These are just a few of the memes featuring in a Youm 7 article. The sarcastic lines imitate the manner in which fathers often talk to their sons, while also mocking their know-it-all attitude and tendency to exaggerate [ $\nearrow$ Young $\boldsymbol{w}$ s. Settled]. Regardless of time and place, Egyptian fathers have a certain way of talking to their children, which inevitably shows their affinity to overstate the virtues of the past, comparing its style, music and education to that of today. From all memes the same face is staring back: a portrait of a slightly sceptical-looking Husnī Mubārak. The political and the biological paternal figure hand in hand. Is he an embodiment of all Egyptian fathers or a person whose authority was ultimately rejected? It is perhaps a bit of both, with the ousted president representing all members of the Mubārak generation and their complicated, yet standard, relationship with their offspring [ $\nearrow$ Past vs. Present, $\lambda$ Present $=$ Past (Stuck)].

And complicated this relationship is. The Atlantic celebrates the fifth anniversary of the January Revolution with an article bearing the rather gloomy title "A Revolution Devours Its Children," which follows the life of five Egyptian families who have close relatives detained on political charges [ $\nearrow$ Disappearances]. Heavily appropriated for a foreign audience, the piece delves into the stories of the five families, all trying to cope with the absence of their loved ones. Most of it revolves around the daily struggles: the long queues at the prison, the weekly 20-minutes-long visitations, the pain of (not) knowing what the future holds [ $\neg$ Prison]. Inevitably, some of the conversations move towards the reason for the detention, revealing a generational $\lambda$ Clash. "This generation wants to live their life, in their own style," "Nūrhān started to feel that she and Ahmad belong to one team, and that we belong to a different team," "His father told him then that the country's youth were foolish, that the 'deep state' would prevail," recalls the mother of the detained activist Ahmad Dawma. The past few years have put a rift between the family members who disagree on what the right path for Egypt is, especially after Ahmad's father publicly supported his son's arrest by the Muslim Brotherhood in 2012. Despite now sharing a common enemy, the family remains divided by a deep sense of mistrust. However, not just politics but also the absence of it could create a gap between family members. Two years ago, in April 2014, 21-year-old Muhammad Imām, according to his friends a member of the April 6 Youth Movement, had been arrested following a protest at the University of Alexandria. His father, a retired military officer, now has a different story to tell. "We are not allowed to get involved in politics," "Me, I don't have any opinions on all that." He has not visited his son in prison yet. "Nothing is wrong with Egypt," Muhammad's mother adds, "We're not a politically interested family, we don't like politics, we don't even know what April 6 is." The guidelines for the family's political and social conduct are set. Having failed to follow the advice to respect the authority of the paternal figure, the sons have been punished by both the actual and the figurative fathers.

Not that the relationship is any simpler at the other end: 
When you meet a male friend while you're with your parents somewhere and you guys make that awkward eye contact that means DO NOT DO CHEEK KISSES, DO NOT DO HUGS; only stiff handshakes are allowed. In fact, if you can limit touching altogether, all the better. Baba is watching,

states number three on the list of "Fifteen Egyptian girl problems," posted on Cairoscene. Today, the life of the Egyptian girls is not easy. Questions about marriage, comments about cooking skills, and constant monitoring of their whereabouts are just part of the things girls have to endure from their parents. All coupled with having to pretend to abide by rules with which they clearly disagree. "The fuck do I care what the bawwāb thinks? ... Apparently everybody's primary concern in life is to scrutinize yours," bellows the author defiantly [ $\lambda$ Freedom vs. Constraint, $\lambda$ Young vs. Settled]. A showcase of the double lives children often live because of their parents, torn between compliance and rebellion, both respecting and challenging the authority of the Father Figure and the social system it represents [ $\nearrow$ Dual Identities / Masking, 7 True vs. False].

And they are questioning the rationale behind the various rules of civility. Blogging for Madā Mașr, Hiba 'Afîfi gives her take on the issue. Soon it will be Ramadan again, the month of soap-watching marathons and endless awkward social events that are impossible to avoid, Ifțār meals, for instance, accompanied by painfully long forced conversations with people with whom you have nothing in common. And it is not just Ramadan that brings out the worst of social obligations. Being forced to attend weddings and funerals of distant relatives and acquaintances whom you barely know also creates this feeling of unnecessary intrusion in people's personal space [ $\lambda$ Freedom vs. Constraint (Individuality $v s$. Collectivity)]. The case, of course, is not against all social gatherings. Rather, the problem is with social obligations that only serve the purpose of maintaining appearances and upholding archaic social rules. Isn't it time to stop clinging to a lifestyle that contradicts its original intention of creating deep and meaningful relationships? Or, to paraphrase the words of Cairo rock band Cairokee:

There are traditions that become defects and need to be changed. Freedom means change, how to express yourself is your choice and not somebody else's. Things are not going well. The old man is trying to bring the past back, while controlling the present. The whole society is united against change, but they can't take away the voice of the people.

An unruly cry against all those who try to restrict freedom and impose their own ideas on the rest [ $\lambda$ "The System" vs. "The People", 入Freedom vs. Constraint (Individuality vs. Collectivity)]. All those who control life, all old men, all Father figures.

"Long live Egypt... Long live Egypt... Long live Egypt," explodes the conference hall as el-Sisi prepares to give the concluding speech of the First National Youth Conference. "I am very happy to be among my sons and daughters, the youth of Egypt," begins the president. The last few days have demonstrated, he elaborates, that the young people of Egypt are capable and enthusiastic and that through receiving proper training, advice and guidance they can become a driving force of Egypt of tomorrow. The country is young, and the youth represents national wealth, which should be developed and invested in. The government will work towards reviewing the status of the detained young people (applause!), developing

jais • 21 (2021) - Themed Section In2016: *111-*123 
training programmes, discussing amendments in the Protest Law and ensuring the continuation of Egypt's cultural and historical identity. The young population, el-Sisi goes on, has been somewhat neglected and marginalized. But Egypt belongs to everyone and only those who want to do harm have no place here. Like his Tunisian counterpart, el-Sisi is concerned about the lack of national unity and he surely has a solution to this problem. He, the President, will work with all young people because a father loves all his children and he hopes that one day one of the young Egyptians will take his place. "Long live Egypt... Long live Egypt... Long live Egypt," concludes the Protector, Provider and Supporter, the Father of the Youth of Egypt.

El-Sisi will work with all young people? But where is this youth he is talking about?, Egyptians ask themselves on Twitter, after the hashtag Where is the youth? explodes yet again on the platform. "Behind bars or buried in their graves," the answer comes. "If el-Sisi held his conference in prison, there would have been a larger attendance," jokes one Egyptian, as many others share pictures of the young people detained, sentenced or killed since 2013 [ $\nearrow$ Disappearances, $\lambda$ Prison, $\lambda$ Young $v S$. Settled]. "I have a message for you...," says a drawing of an overweight Egyptian official, as he pokes his head through the barred door of a prison cell, with the words "Egyptian youth" next to it, "You are the hope and the future of Egypt" [ЛInferiority = Superiority (Satire)]. The Egyptian youth, like their coevals in Tunisia, need actions, not words. It is time for real change, not empty promises. The young Egyptians are fed up with the "Father" discourse and the words that fail to deliver in practice. Acting like an almighty figure of authority is no longer enough, the role of the father-leader is becoming obsolete.

"The Egyptian youth are children only to their parents," rails 'Umar al-Hādi from the virtual pages of al-Mașri al-Yawm. Again, this critiques the notion of the "Father-President" which has been harming Egypt for decades. The youth are not the president's children, they are citizens with rights and obligations. They demand freedom and dignity and el-Sisi addressing them as his sons and daughters is just an insult. Treating them as children who need presidential advice is not going to solve the youth crisis. The country's restraint towards the people has been great during the last few years, states el-Sisi, to avoid the current state of tension. How come? Is he forgetting that the state is the state of the people? Is he forgetting the great self-restraint people had to impose on themselves when dealing with the actions of the regime? [ $\nearrow$ Baby Milk, $\nearrow$ Dollar Crisis]. The angry monologue continues: The people have not wrecked the Egyptian economy, they have not ignored the problems in the security services until the crimes committed by policemen occupy half of the incident page in alAhrām, they did not transfer the two islands to Saudi Arabia [ $\nearrow$ The Policeman Criminal, $\nearrow$ Red Sea Islands, $\nearrow$ Tricking the System / Tricked by the System]. The people did not kill Giulio Regeni and they did not imprison Ahmmad Nāgī for his comics [ $\nearrow$ Court Trials] and Islam Behery (Islām Buhayrī) for his ideas [ $\nearrow$ Prison]. Egypt needs a state that respects the constitution and the rights and the freedom of its people. The Egyptians want a president of a modern secular state and not a father, a leader or a caliph. Al-Hādī's final remark brings the tirade to an abrupt stop, leaving the reader suddenly aware of the emotional charge of the words and the power of the silence that follows. It is not just a rejection of el-Sisi but of the entire notion of the Father Figure, in all its complexity, and the social and political system built around it. 


\section{Related Entries}

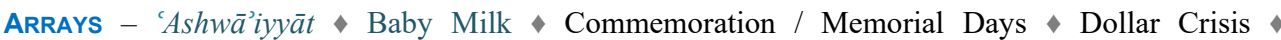

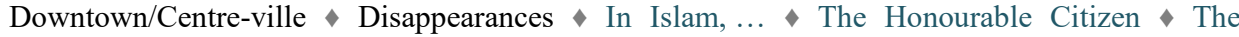
Policeman Criminal $\downarrow$ Prison $\downarrow$ Red Sea Islands $\downarrow$ The Suspect Foreigner $\downarrow$ Tricking the System $/$ Tricked by the System $\downarrow$ The Voice from Above

CODES - Freedom vs. Constraint (Individuality $v s$. Collectivity) $\diamond$ Past $v s$. Present $\downarrow$ Security $v s$. Fear True $v s$. False Voice $v s$. Silence Young vs. Settled

CODES COLLAPSED - Inferiority $=$ Superiority $($ Satire $) \diamond$ Present $=$ Past $($ Stuck $) \diamond$ Security $=$ Fear $($ Police State)

\section{References}

The Atlantic. "A Revolution Devours Its Children." January 23, 2016, <https://www.theatlantic.com/ international/archive/2016/01/egypt-revolution-arab-spring/426609/>.

Cairokee. "Ākhir ughniyya." March 12, 2016, <https://youtu.be/TZu2euuj2GE>.

Cairoscene. "15 Egyptian girl problems you can probably relate to." April 2, 2016, <http:// www.cairoscene.com/LifeStyle/15-Egyptian-Girl-Problems-You-Can-Probably-Relate-To>.

Facebook post, May 4, 2016, https://www.facebook.com/photo.php?fbid=1620050588319279\&set= p.1620050588319279\&type $=1$ \&opaqueCursor=AbqqKX8_uQwfYeWZ4QNi3qYUXL9vcSrGCN MyuWsxeKpi4k92QFWFfjKCC5rSJMZzklnFCwE-0zx-87V6Wu7z5IwZGCenZAw1m_ 7Tfxd2 obU9Z8BSWprE4wUaDeDC Ts4zNBA79cOA tNih1gq-SOOhV-1wyhbWfZAjIiFH11mr2pJ9kPJwP7ktWxoupAluQ7oskRpKgDwMLZsnNR8AqYPu7x51kWMprZ2JoBBonhJy8JwYdz4lzY G0qW8bptPO1dSduKi6FB5q4gHp1RQwCdtwzAeJkNFMYPssTSn6XttMsE5s8dJSHg2-aH8jj 5hAi0I2wMmJidSHaVmDqPJG0VrkkBag88XPq_TWpkLP36r7UYcl7q58Y9zvWepcAztKY15v yq3FIz2o7YH438RPW7mpIafX-PQGasak710-d-O62mg\&theater.

Jīhān al-Ṭāhirī. Egypt's Modern Pharaohs. Available on YouTube, posted $26^{\text {th }}$ January 2016, 2016, $<$ https:// youtu.be/YvZ_ngOvsgk>.

"Khayr agnād al-arḍ." Facebook post, December 28, 2016, <https://www.facebook.com/Khair.Agnad. Elard/posts/1649053595110028>.

"Kullunā rijāl al-shurța al-mașriyya." Facebook post, April 11, 2016, <https://www.facebook.com/ elking.mohamed.89/photos/a.393231024089612.94224.393222587423789/998128573599851>.

Madā Mașr. "The case against social obligations." July 28, 2016, <https://www.madamasr.com/en/ 2016/06/20/opinion/society/blog-the-case-against-social-obligations/amp/>.

"Mașr lil-gamī' wa-bil-gamī'." Facebook post, March 9, 2016, <https://www.facebook.com/ 1Tamer.Asfour/photos/a.363452263709580.90414.152451254809683/953258231395644>.

"Mașr lil-gamī' wa-bil-gamī`." Facebook post, April 23, 2016, <https://www.facebook.com/1Tamer. Asfour/photos/a.363452263709580.90414.152451254809683/985198328201634>.

"al-Ra'̄̄s 'Abd al-Fattāh al-Sīsī." Facebook post, August 27, 2016, <https://www.facebook.com/ 73sisilovers/posts/1753242544926260>.

“\#al-Sīsī șāyin arḍuh.” Facebook post, April 12, 2016, <https://www.facebook.com/permalink. php? story_fbid $=10153699358054790 \& \mathrm{id}=529354789>$.

al-Sīsī, 'Abd al-Fattāh. Speech, given at the First National Youth Conference, October 27, 2016, $<$ https://youtu.be/asIPXP5uI1Y>.

زحز • 21 (2021) - Themed Section In2016: *111_*123 
“Șuwar Mașr Zamān.” Facebook post, January 29, 2016, <https://www.facebook.com/sewarmisr/ posts/755518071249270>.

Twitter, "il-shabāb fēn?" Most popular hashtag on October 26, 2016, <https://twitter.com/search? vertical=default\&q=\%23\% فين_الشباب:>

'Umar al-Hādī. "al-Shabāb muwāținūn ... wa-laysū abnāak." al-Maṣrī al-Yawm, October 27, 2016 , $<$ http://www. almasryalyoum.com/news/details/1031314>.

Youm7. "10 gumal ta'kis țabīat al-ab al-miṣrī al-așîl: bi-ṣawt Ḥusnī Mubārak," F, sebruary 11, 2016,

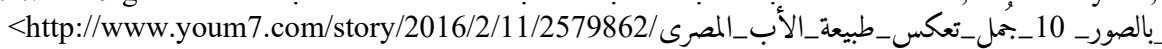

_الأصيل_بصوت_حسنى.

4mly201@yahoo.co.uk

\section{... in Tunisia}

“Weldek fi darek!” The return of the Supreme Combatant

By JOACHIM BEN YAKOUB

Not long after its official inauguration, two rebellious students tag the marble pedestal of the legendary equine statue of first president of independent Tunisia. Ghassen Bouazzi, head of the syndicalist student movement and Hamza Nasri, activist of the Popular Front, adorn the foot of the presidential sculpture with the phrase weldek fi dārek ("Your children should stay in your house") and added we-nsībek zēda ("and your brother-in-law too"). \#weldekfidarek is only recently going viral after the catchy three word slogan was first thrown in the Parliamentary Assembly for the renewal of trust in the government Habib Essid by one of the deputies of the Popular Front [ $\nearrow$ Social Media]. It is a direct message to president Beji Caid Essebsi not to favor his son Hafedh's accession in political life as head of 'Nida Tunes'. The complementary phrase referring to the brother-in-law, is meant for Youssef Chahed to question his potential nomination as head of the government of National Unity. The graffiti action echoes the griefs of a growing part of the population, apparently fed up with the seemingly persistent regime nepotism, now hiding behind a veil of historicity [ $\nearrow$ Manissh $m s \bar{a} m i h]$. Bouizi an Hasri are eventually arrested for vandalizing the statue and accused of offense against the head of state, but the Court eventually dismisses their case [ $\nearrow$ Court Trials].

On a regular working Tuesday morning in May, commuters and passers-by on Bourguiba Avenue bump into a new statue in front of Ministry of the Interior in Tunis [ DDowntown/Centre-ville]. Still packed in plastic, it shows the contours of a recognizable and familiar form. It surely is not any statue, but thé triumphal equine statue of Habib Bourguiba, once displaced by Ben Ali to the port town in the Northern suburb of Tunis. As promised during the presidential elections and as he already stated seven years before in his visionary memoire "Habib Bourguiba: the wheat and the chaff", Beji Caid Essebsi, the first elected president in post-revolutionary Tunisia, brings back the father of the nation in the center of public attention. The equestrian statue is effectively unbolted and removed from its previous location in La Goulette, where it stood for 29 years. As commuter can see with their 
own eyes, the statue now stands in front of the Clock Tower, on exact the same place as once thousands of protesters stood demanding the departure of Ben Ali [ $ス$ "The System" vs. "The People"]. It is not sure if - with the benefits of hindsight - the masses would converge again to wipe out the autocrat. As 7 views, a clever documentary by Lilia BLAISE and Amine BOUFAIED convincingly shows, it did not take long for a considerable part of society to publicly express their regret to have ousted their president and to admit their nostalgia for the times before the revolution, when Zine El Abdine was leading the country as a firm but fair leader. Seen from this vantage point, the return of the 'Supreme Combattant' is a strategic move. After all, there can be only one pater familias.

The return of the image of Bourguiba does not come as a surprise. Most people notice how, since the presidential elections, the new president of the republic assimilates different features of the "Eternal Leader". He adopts a same form of speech, rich in popular proverbs, altered by sporadic Koranic verses, often time using sharp and applicable allegories, always spiced with a subtle sense of humor. Even his looks, especially the glasses and his body language reminds that of his predecessor, making the same gestures, particularly with his hands. To manage the massive protest in the region of Kasserine and beyond after the cruel death of Ridha Yahyaoui, the president makes a curious appearance on public television [ $\neg$ "The System" vs. "The People"]. Everybody can see that the presidential address is filmed from exact the same decorative setting as Habib Bourguiba speech that contained the bread revolt in 1984. Now, to contain the riots that followed unfulfilled employment promises by the government in Kasserine but spread again all over the country, the president is addressing the people sitting behind the same desk, with the national flag on his left and in front of the same classic brownish map of Tunisia framed in leather with golden stars. Different memes are spreading across social media, mocking "Bajbouj" his unabashed mimicry. The most viral diversion comes from Anour L. who pastes a "Confused Travolta" in the historical setting and created an animated GIF making John Travolta wonder how history could repeat in such literal sense over a period of only 32 years [ $\lambda$ Present $=$ Past (Stuck), $\nearrow$ Social Media].

Different politicians, artists and activists are annoyed by the decision to reinstate the Bourguibist imagery, supposedly unbefitting the context of growing marginalization and revolt [ $\lambda$ Affluence $v s$. Destitution]. Mohamed Abbou (Ex-CPR and founding member of the "Democratic Current") is one of the first politicians to publicly contest the return of the image of the 'Father of the Nation' and proposes to launch a contest for artist to imagine a monument that would symbolize "the end of dictatorship". Architect Ahmed Zaouche endorses that proposition as it should mobilize the whole city in a democratic way through an extensive consultation. Under the title "One of the most important achievements" a certain Malek Feki uploads a series of digitally altered images of the concerned equestrian statue, so it salutes from atop of a garbage pile in the city center, in the middle of a street blocking the way of a congested bus, on the roof of a concrete container school, somewhere in the South of the country in a desert in the background of a hungry Bedouin family or somewhere in a city as witness to flooding streets [ $\lambda$ Social Media, $\lambda$ PAlsh, $\lambda$ Affluence $v s$. Destitution] In Feki's collage, Bourguiba is no longer proudly saluting 'his' people, but real social and environmental issues. The series resonates with the critique by Rym Thairi of the 'Mahaba 
Current'. In the 'Assembly of Representatives of the People', Thairi condemns the monumental intervention as unjustifiable, trivial, futile and even counter-revolutionary symbolic politics. Taking into account the precarious socio-economic condition of the country, it would neglect what he considers the real preoccupations of the people [ $\nearrow$ "The System" vs. "The People", $\lambda$ Affluence vs. Destitution].

On the other hand, according to an op-ed written by architect Moncef Kamoun on the Kapitalis website, Bourguiba is today, even without its equine statue, more present and more alive than ever before. Bringing the equestrian monument back to its original place is therefore the least you can do as a recognition to "one of the few true modernist references" in an "Arab world that is looking to the past and haunted by the forces of death". Renown Professor Mohamed Kerrou also writes in the Huffington Post, that the political use and rehabilitation of the charisma of the 'Father of the Nation' can be understood as a form of resistance to the "Islamist and populist threat" engendered by the Troika before the elections. The popular historian Kmar BENDANA joins the debate with a contribution in Le Quotidien d'Oran and states that the return of the Bourguibist imagery is the logic consequence of the ubiquitous "present absence" of Tunisia's former leader in the last two decennia. When Ben Ali took power in 1987, Bourguiba was put on house arrest, from the day of the coup until his death April, $6^{\text {th }} 2000$. The regime not only removed every reference to the legacy of the former president, it also actively silenced Neo-Destourian partisans and Bourguiba loyalists. His 17 yearlong permanent isolation and abandonment passed without public opposition, until the day of his death. His coffin, embellished with a portrait depicting him as an old sick man, was carried from Tunis to Monastir in the belly of a purple plane stamped with a "November 7" logo, referring to the official regime imagery praising "the change" Ben Ali allegedly brought to the country. The funeral was not even broadcasted on national television. In short, the death of "The Father of the Nation" was never properly mourned over. Bendana thus argues that this unchallenged abandonment still carries its repercussions today, enhancing a feeling of guilt, remorse and frustration over the fact the Zaïm never really received a rightful place in national history. In a unexpected post-revolutionary context lacking clear leadership, this discontentment only reinforces the general appeal to Bourguibist symbolism.

Evoking an ounce of the legacy of Bourguiba during "The Era of Change" was indeed unthinkable and nearly considered a form of treason [ 7 Freedom $\nu$ s. Constraint]. During the autocratic times of the Ben Ali regime, different artist nevertheless engaged with the imagery of the "Father of the Nation" as a form of dissent. The photograph of the de-located statue of Bourguiba in La Goulette, central in Faten Gaddes's series "La Rue" exposed at the Ammar Farhat art gallery in 2009, not only shows the regime's wish to eradicate the historical event of national return in 1955 that the statue represents, it also sensibly illustrates the ongoing process of irreverent demarcation. The image of a bronze Bourguiba sitting on the back of his horse, apparently standing on the dilapidated and nearly collapsing construction site in La Goullette instead of the marble pedestal, is also testimony to the expropriation of some long-time residents of what was once known as Tunisia's Little Sicily for the benefit of lucrative real estate projects closely connected to the regime [ $\left.\nearrow^{c} A s h w \bar{a}^{\prime} i y y \bar{a} t\right]$. The graffiti stencil of Wassim Ghoslani (2002), the Warholian screenprints of Bassem Jelali, the speed-painting of Selim Tlili (2010) or the painting of Mehdi Bouanani (2010) also show the dissidence engrained in the reproduction of Bourguiba's portrait during the Ben Ali Era. Mehdi Bouanani, for instance,

jaig • 21 (2021) - Themed Section In2016: *111-*123 
crossed the border of political sensibility with his painting of different portraits of Bourguiba. When he tried to exhibit his paintings in an art gallery in 2010, he was refused entry by Tunisian customs, and had to submit to a police interrogation. His exhibition was eventually canceled.

The most cutting edge response to the return of the Bourguibis imagery comes from art philosopher Adnen Jdey in an op-ed for the online Nawaat platform, where he compares the second life of the statue of Bourguiba to the figure of Don Quixote, galloping and confusing the order of the real and the symbolic to reinforce the prevailing political consensus. The double exile and the double triumphal return of the Zaïm, once in 1978 and once in 2016, functions as a fiduciary jouissance facilitating the real reproducibility of the status quo. For Adnen the two apparent different bodies of Bourguiba, the patriot and the despot, the "supreme combatant" and the "enlightened tyrant" are two different sides of the same coin, that throws a shadow on the still present Novemberist Clock Tower that together with the equestrian statue form the still erect phallus of an entrenched power structure.

Despite all criticism, the great return is inaugurated on "Victory Day", the first of June, for the celebration of the 60th anniversary of the mythical return of Bourguiba from exile in 1955 [ Л Commemoration / Memorial Days]. Escorted by security services and covered by a dozen security agents, Beji Caid Essbsi is welcomed by Mariem Bourguiba the granddaughter of the first "Father of the nation", her husband and a couple of others highly esteemed guests, before opening the red curtains, hiding the golden inscription on the marble pedestal of the equine monument. The famed filmmaker Hicham Ben Ammar is the only one noticing the absence of the sculptor of the original statue, Marzouk Hechmi. He stands there all by himself behind the security fences, humiliated and hurt - nearly crying - during what he imagined would be the apotheosis of his oeuvre. Notwithstanding Marzouk passionately worked for months to restore what he considers his lifetime achievement, he is apparently not invited to the ceremonial inauguration [ 7 The Honourable Citizen, 7 Hope vs. Hell]. Inside the security perimeter, surrounded by a horde of journalist, Essebsi explains he choose today as an inauguration date not to re-instate a new personality cult, but to commemorate a day of national cohesion without precedent. For Essebsi, the return of the imagery of Bourguiba answers a shared need for a solid national unity. It is a condition sine qua non to get Tunisia out of the situation it has fallen in since the revolution. The president further reminds the journalists present that the Bourguiba Avenue, used to be named after Jules Ferry and that the statue of Bourguiba replaces the one of the instigator of the French protectorate. Beji Caid Essbsi tries to convince the journalists and their audience that a symbol of colonization is replaced by a symbol of liberty and independence.

The statue of Ferry was indeed the most imposing emblem of the protectorate, embodying the French civilizing mission [ $\nearrow$ Inferiority $\nu$ s. Superiority]. Placed vertically in height, the monument sculpted by Antonin Mercie faced the city, Feery's back turned to the Mediterranean port, looking down from his pedestal to three subservient bronze figures: a Bedouin statuette offering a bundle of wheat, a settler colonist looking up in full admiration and a schoolboy looking up towards Jules Ferry, in honor of his role in educational development. After being dismantled, the statue of Jules Ferry, was temporarily stocked on an island on the Lake of Tunis. The Municipality of Tunis has however never fulfilled her intention to offer the unbolted statue to the municipality of Saint Dié, the hometown of Ferry. The statue of Jules Ferry is now indeed replaced by the one of Bourguiba, that eternalizes the image of the 
historical moment when Bourguiba, the "Mujahid El Akbar" or "Supreme Combattant" returned from exile from Brittany's Groix Island, in the port town of La Goulette, after signing the Franco-Tunisian agreement recognizing the internal autonomy of Tunisia, June 1, 1955 [ ZPrison]. Reminiscent of the equestrian statue of Louis XV on the Place de la Concorde in Paris, the statue of Bourguiba pursues the French Monarchical trend in equestrian monumentalization [ $\nearrow$ Inferiority $v s$. Superiority, $\lambda$ Dual Identities / Masking]. The president is monumentalized strongly perched on a galloping horse, confidently and triumphantly saluting the cheering mass, dressed in a modern tailored suite and a fez, the traditional ottoman red hat.

The comeback of Bourguiba in the capital is not the first, nor the last time the government decides to move its historical markers, making the whole effort a national endeavor [ $\lambda$ Center vs. Periphery]. As the wave of protest in Kasserine settles down, a truck deposes a restored bronze equestrian statue in front of the presidential palace of Skanès (Ksar Al Marmar) at the entrance of the city. The statue depicts the Zaïm wearing not a fez but a mdhalla, a traditional straw hat [ $\nearrow$ Beautiful $v s$. Ugly]. It also seems to be from the hand of sculpture Hechmi Marzouk, but was originally erected in the city of Kairouan. It had first to be restored, as it was vandalized in the aftermath of the 2011 revolution, but captured by the military who kept it save in the casern of Sidi Saâd. The equestrian statue is unveiled by president Beji Caid Essebsi in person, during the festivities commemorating the $16^{\text {th }}$ anniversary of Bourguiba's death [ $\lambda$ Commemoration / Memorial Days]. One of the statues symbolizing Bourguiba's triumphant return in 1955, is also resettled in the coastal city of Sousse. The equestrian statue was relocated to its former location as it was installed in 1977 at the intersection of Bab Bhar, [7Downtown/Centre-ville] Sousse. The inauguration, planned for the celebrations of 'Republic Day', the date of the establishment of the Republican regime on July 25th is postponed until August $13^{\text {th }}$ for the celebration of the 60th anniversary of the promulgation of the personal status code, the historical code that facilitated the emancipation of "La Femme Tunisienne" under Bourguiba [ $\lambda$ Commemoration / Memorial Days]. The vacant place of the father is indeed eagerly solicited, in contrast to the figure of the mother that remains largely unnoticed and unmentioned [ $\lambda$ Male $v$ s. Female].

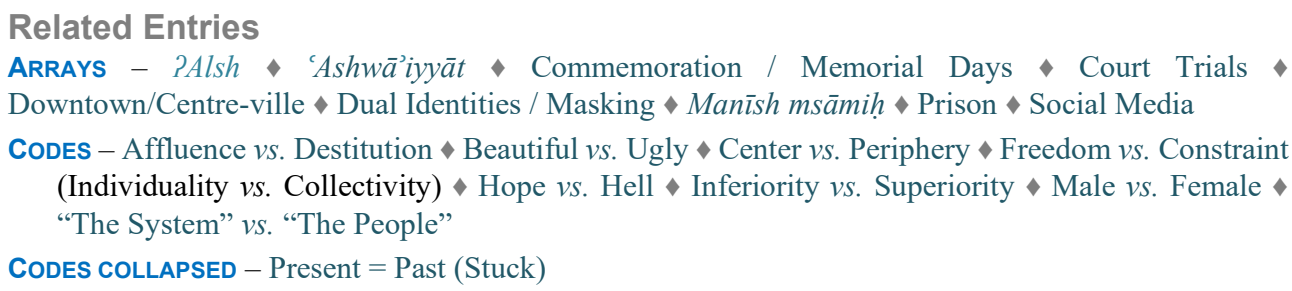

\section{References}

BENDANA, K. "Bourguiba : la présence de l'absent." Le Quotidien d'Oran, April 7, 2016.

BlAise, L. and A. BoufAiEd. 7 vies. Tunis: Antworks productions, 2014.

Chaouch, R. "Carte interactive : ces statues qui font polémique au Maghreb." Jeune Afrique, April 1, 2016, <www.jeuneafrique.com>.

Essebsi, B. C. Habib Bourguiba : Le Bon Grain et l'Ivraie. Tunis: Sud Éditions, 2009.

jaig • 21 (2021) - Themed Section In2016: *111-*123 
JDEY, A. “Bourguiba, la statue et l'érotique du système." Nawaat.org, May 28, 2016.

Kamoun, M. "La Tunisie et l'eternel retour de Bourguiba." Kapitalis.com, March 2, 2016.

Kerrou, M. "Usages politiques de Bourguiba et du bourguibisme.” Huffpostmaghreb.com, April 7, 2016.

\Joachim.BenYakoub@UGent.be • 